\title{
Evaluation of Private and Public Maize Hybrids for Their Potential Yield Under Northern Transition Zone of Karnataka, India
}

\author{
M.G. Pradeep ${ }^{1^{*}}$ and R.H. Patil ${ }^{2}$ \\ ${ }^{1}$ Department of Agronomy, ${ }^{2}$ Department of Environmental Sciences, College of Agriculture, \\ University of Agricultural Sciences, Dharwad - 580 005, Karnataka, India \\ *Corresponding author
}

\begin{tabular}{|c|c|}
\hline & A B S T R A C T \\
\hline & \multirow{6}{*}{$\begin{array}{l}\text { The field experiment was conducted during kharif season of } 2016 \text { on deep black soil at the } \\
\text { Main Agricultural Research Station, University of Agricultural Sciences, Dharwad, } \\
\text { Karnataka, India under potential condition. The experiment consisted of } 36 \text { maize hybrids } \\
\text { ( } 21 \text { private and } 15 \text { public sourced) replicated twice and laid out in Randomised Complete } \\
\text { Block Design. The phenology, leaf area index, yield traits and grain yield were recorded } \\
\text { and statistically analysed for comparison amongst the hybrids. The study showed that } \\
\text { private hybrids outperformed the public hybrids in both growth and yield parameters. The } \\
\text { private hybrids had mean LAI value of } 2.26,4.27 \text { and } 2.51 \text { at } 30 \text { DAS, } 70 \text { DAS and a } \\
\text { harvest compared with mean LAI values of } 1.85,3.54 \text { and } 1.59 \text {, respectively, by public } \\
\text { hybrids. The highest grain yield among the private hybrids was recorded by DKC-9141 } \\
\text { (11492 kg ha-1) compared to the highest among public hybrid GH- } 15305 \text { ( } 9227 \mathrm{~kg} \mathrm{ha}^{-1} \text { ) } \\
\text { and the difference was } 19.8 \text { per cent. The lowest yield of } 6631 \mathrm{~kg}^{-1} \text { was recorded by a } \\
\text { public hybrid GH-1314 which was } 22.1 \text { per cent lower than the lowest yield of } 8511 \mathrm{~kg} \text { ha } \\
{ }^{1} \text { recorded by the private hybrid NMH- } 145 \text {. }\end{array}$} \\
\hline Keywor & \\
\hline $\begin{array}{l}\text { Evalu } \\
\text { and p } \\
\text { hybri }\end{array}$ & \\
\hline Article Info & \\
\hline $\begin{array}{l}\text { Accepted: } \\
26 \text { October } \\
\text { Available } \\
10 \text { Decemb }\end{array}$ & \\
\hline & \\
\hline
\end{tabular}

\section{Introduction}

Maize (Zea mays L.) is the most important cereal crop in the world after wheat and rice. Globally, it's grown on an area of $177 \mathrm{~m}$ ha, with a production of $967 \mathrm{~m} \mathrm{t}$ at an average productivity of $5.5 \mathrm{t} \mathrm{ha}^{-1}$ (Anon., 2014). Maize is also called "Queen of Cereals" because of its high production potential and wider adaptability. In India, it is cultivated on an area of $9.4 \mathrm{~m}$ ha with a production of $23 \mathrm{~m}$ $\mathrm{t}$ at a productivity of $2540 \mathrm{~kg} \mathrm{ha}^{-1}$, which is less than half the global average. In Karnataka, maize is cultivated on an area of $1.36 \mathrm{~m}$ ha with a production of $4.4 \mathrm{~m} \mathrm{t}$ at an average productivity of about $3500 \mathrm{~kg} \mathrm{ha}^{-1}$,
(Anon., 2014) which is again lower than the global average productivity, but higher than national average. Karnataka stands first in maize production in India with a share of $6 \%$ in total area and $12 \%$ of the total maize production of the country. Even after being the leading producer, farmers of the state are still unaware of suitability of hybrids available in the market which are developed by both private and public institutions. Farmers still tend to use the readily available hybrids without knowing the suitability of the hybrid to their location and resources at their disposal. This not only affects the achievable yield but also the production and profitability. 
Therefore this study was undertaken with an objective of screening different private and public maize hybrids to know their potential yield under Northern Transition Zone of Karnataka on black soil.

\section{Materials and Methods}

The present study was conducted during kharif season of 2016 on deep black soils at the Main Agricultural Research Station, University of Agricultural Sciences, Dharwad (Karnataka) under potential condition i.e., irrigation was provided at regular interval to supplement deficit rainfall to make sure the crop did not experience moisture stress. Hence NPK (150:60:60 kg $\left.\mathrm{ha}^{-1}\right)$ recommended for irrigated maize was applied following package of practices. The experiment was laid down using Randomised Block Design (RBD) with two replications and the plot size of $4.8 \times 3.0 \mathrm{~m}$ and spacing of $60 \times 30 \mathrm{~cm}$ were used. The materials for the present study included of two sets of hybrids i.e., Private and Public maize hybrids which were obtained from different Private and Government Organizations presently operating in Karnataka. A total of 36 hybrids were included. The kharif crop seeds of all the hybrids were sown on $10^{\text {th }}$ of June 2016 and harvested at once on November $5^{\text {th }}$ of 2016 , but days to physiological maturity varied amongst them. Hand weeding operation was carried out periodically thrice during the crop growth stage at 20,35 and 45 DAS to keep the plot weed free. Two inter-cultivation operations were done to enable earthing up and to remove weeds present between crop rows. No incidence of disease was noticed in the crop during the growing period, but quinolphos was sprayed @ $2.0 \mathrm{ml} / \mathrm{lt}$. to manage stem borer incidence. These 36 hybrids were classified into three maturity groups: early maturing (100-110 DAS), medium maturing (110-120 DAS) and late maturing (120-130 DAS).

For collecting data on crop for each treatment, five plants were selected randomly and they were tagged. These tagged plants were used for recording the growth and yield parameters. Leaf area index and biomass were recorded from one of the randomly selected plants as destructive sample from within the plot, whereas, final yield and yield attributing observations were recorded for both the tagged plants and net plot.

The cob length was recorded by measuring the cob from the tip to base and expressed in centimetres. The circumference of the cob was measured at the centre of the cob using the vernier callipers and was expressed as the girth of the cob in centimetres. The average number of grain rows $\operatorname{cob}^{-1}$ was worked out by counting the total rows from all the observational cobs and dividing them by total number of cobs. After shelling the cobs, the grain yield from net plot was recorded and yield $\mathrm{ha}^{-1}$ was calculated. The test weight was recorded by counting 100 grains obtained from the observational cobs which were dried, weighed and expressed in grams.

\section{Results and Discussion}

\section{Leaf area index}

Leaf area index was measured at three different stages i.e., at 30 DAS, 70 DAS and at harvest. The mean LAI of private hybrids were $2.26,4.27$ and 2.51 at 30 DAS, 70 DAS and at harvest, respectively. The LAI ranged from 1.67 to 2.83 (30 DAS), 3.42 to 5.03 (70 DAS) and 1.58 to 3.48 (at harvest). The highest LAI was recorded in hybrid DKC9141 at all the three stages $(2.83,5.03$ and 3.48). It was on par with D-4685 $(2.78,4.96$ and 3.24) and was followed by GK-3150 (2.68, 4.87 and 3.19). The lowest LAI was recorded by the hybrid NMH-145 (1.67, 3.42 and 1.58), which was followed by NK-6240 $(1.77,3.56$ and 1.61) at $30 \mathrm{DAS}, 70 \mathrm{DAS}$ and at harvest, respectively (Table 1).

Amongst the public hybrids the mean LAI 
were found to be 1.85 (30 DAS), 3.54 (70 DAS) and 1.59 (at harvest). The LAI in public hybrids ranged from 1.51 to 2.19 (30 DAS), 2.64 to 4.24 (70 DAS) and 1.16 to 2.33 (at harvest). The highest LAI was recorded by GH-15305 (2.19, 4.24 and 2.33), followed by DMH-3 (2.13, 4.19 and 2.21) and GH-15060 (2.04, 4.02 and 2.13). The lowest LAI was recorded by the hybrid $\mathrm{GH}-0727$ (1.51, 2.64 and 1.16), followed by $\mathrm{GH}-1314$ (1.63, 2.88 and 1.29). This was in agreement with results of Dahmardeh and Dahmardeh (2010) where they reported that short season cultivar SC108 produced less leaf area than long season cultivars SC-604 and SC-704, as a result long season cultivar had greater LAI and dry matter accumulation than short season cultivars. Among all the 36 hybrids, private hybrids recorded higher LAI compared to the public hybrids and at all the stages. The highest LAI among all the hybrids was recorded by DKC-9141 with 2.83, 5.03 and 3.48 at 30 DAS, 70 DAS and at harvest, respectively. Hara (2003) reported that hybrids differed significantly from each other with respect to number of leaves plant ${ }^{-1}$ at different growth stages of maize, thus affect LAI, too.

\section{Yield attributes}

The cob length showed significant difference among the private hybrids, ranging from 14.8$18.4 \mathrm{~cm}$ with the difference of $4.04 \mathrm{~cm}$ and at a mean value of $16.5 \mathrm{~cm}$. The hybrid $\mathrm{CP}-818$ recorded the highest cob length of $18.4 \mathrm{~cm}$ closely followed by the hybrids D-4685 (18.0 $\mathrm{cm})$, 900-M-GOLD $(17.7 \mathrm{~cm})$. Whereas the lowest cob length was recorded by NMH-145 $(14.8 \mathrm{~cm})$ followed by BISCO PRINCE (15.2 $\mathrm{cm})$ and NK $6240(15.3 \mathrm{~cm})$. Similarly in case of public hybrids the cob length ranged from 12.5 to $16.4 \mathrm{~cm}$ with the difference of $3.9 \mathrm{~cm}$ at a mean value of $15 \mathrm{~cm}$. The highest cob length was recorded by the hybrid GH-15060 $(16.4 \mathrm{~cm})$ followed by $\mathrm{GH}-1316(15.8 \mathrm{~cm})$ and CAH-1574 $(15.7 \mathrm{~cm})$. The lowest cob length was recorded by the hybrid GH-15688 $(12.5 \mathrm{~cm})$ closely followed by $\mathrm{GH}-0727$ (13.2 $\mathrm{cm})$ and $\mathrm{GH}-1314(13.6 \mathrm{~cm})$.

The cob girth among the private hybrids ranged from 14.1 to $16.0 \mathrm{~cm}$ with the mean value of $15.2 \mathrm{~cm}$. The cob girth among the private hybrids also showed difference as the highest cob girth was recorded with hybrid GK-3150 $(16.0 \mathrm{~cm})$, and was on par with P$3401(16.0 \mathrm{~cm})$ and DKC-9141 $(15.7 \mathrm{~cm})$, whereas the lowest cob girth was recorded by the hybrid NMH-145 (14.1 cm), and was closely followed by DKC-9133 (14.4 cm). The mean value of cob girth among the public hybrids was $14.0 \mathrm{~cm}$ with the range of 13.1$15.4 \mathrm{~cm}$. The highest cob girth was noticed in hybrid BRMH-1 $(15.4 \mathrm{~cm})$ which was on par with DMH-3 $(15.4 \mathrm{~cm})$ followed by $\mathrm{GH}-$ $15305(15.3 \mathrm{~cm})$. The lowest cob girth was recorded in hybrid CAH-1574 $(13.6 \mathrm{~cm})$, and was closely followed by GH-1314 $(13.7 \mathrm{~cm})$. Among the different varieties, cv. FH 810 showed maximum plant height, number of grains rows $\mathrm{cob}^{-1}$, cob diameter, numbers grains $\operatorname{cob}^{-1}$, test weight, grain yield, biological yield, harvest index and seed protein contents over cv. DTC and cv. C20 (Haroon et al., 2011) (Table 2).

The number of rows per cob among private hybrids varied from 12.0 to 15.2 rows with the difference of 3.2 rows and with the mean value of 13.5 rows. The highest number of rows per cob was recorded in hybrid 900-MGOLD with 15.1 rows which was closely followed by DKC-9141 (14.8) and CHAMUNDI (14.8). 
Table.1 Leaf area index (LAI) of private and public maize hybrids at different growth stages

\begin{tabular}{|c|c|c|c|c|c|c|c|}
\hline Private hybrids & 30 DAS & 70 DAS & At harvest & Public hybrids & 30 DAS & 70 DAS & At harvest \\
\hline $\mathrm{DKC}-9141$ & $2.83 a$ & $5.03 a$ & $3.48 \mathrm{a}$ & $\mathrm{GH}-150241$ & $1.94 \mathrm{c}-\mathrm{h}$ & $3.97 \mathrm{f}-\mathrm{k}$ & $2.02 \mathrm{e}-\mathrm{m}$ \\
\hline $\mathrm{DKC}-9133$ & $1.93 \mathrm{c}-\mathrm{h}$ & $3.96 \mathrm{f}-\mathrm{k}$ & $2.11 \mathrm{e}-\mathrm{k}$ & GH -0727 & $1.51 \mathrm{~h}$ & $2.64 p$ & $1.16 \mathrm{mn}$ \\
\hline $900 \mathrm{M}-\mathrm{GOLD}$ & $2.50 a-f$ & $4.43 b-g$ & $2.64 b-f$ & $\mathrm{GH}-1427$ & $1.75 \mathrm{e}-\mathrm{h}$ & $3.21 \mathrm{~m}-\mathrm{o}$ & $1.231-n$ \\
\hline $\mathrm{DKC}-9149$ & $1.97 \mathrm{~b}-\mathrm{h}$ & $3.93 \mathrm{f}-\mathrm{k}$ & $2.08 \mathrm{e}-1$ & $\mathrm{GH}-1436$ & $1.85 \mathrm{~d}-\mathrm{h}$ & $3.74 \mathrm{~h}-\mathrm{m}$ & $1.54 \mathrm{~h}-\mathrm{n}$ \\
\hline $\mathrm{DKC}-9126$ & 1.99b-h & $3.99 \mathrm{f}-\mathrm{k}$ & $2.22 \mathrm{~d}-\mathrm{j}$ & $\mathrm{CAH}-1574$ & $1.90 \mathrm{c}-\mathrm{h}$ & $3.86 \mathrm{~g}-1$ & $1.68 \mathrm{~g}-\mathrm{n}$ \\
\hline DKC - 9144 & $1.83 \mathrm{~d}-\mathrm{h}$ & $3.69 \mathrm{i}-\mathrm{m}$ & $1.94 \mathrm{f}-\mathrm{n}$ & $\mathrm{GH}-1314$ & $1.63 \mathrm{gh}$ & $2.88 \mathrm{op}$ & $1.29 \mathrm{k}-\mathrm{n}$ \\
\hline $\mathrm{NK}-6240$ & $1.77 \mathrm{e}-\mathrm{h}$ & $3.56 \mathrm{j}-\mathrm{n}$ & 1.61h-n & $\mathrm{GH}-1316$ & $1.97 \mathrm{~b}-\mathrm{h}$ & $3.92 \mathrm{f}-\mathrm{k}$ & $1.94 \mathrm{f}-\mathrm{n}$ \\
\hline$S-6668$ & $2.44 a-g$ & $4.39 \mathrm{c}-\mathrm{g}$ & $2.62 b-f$ & $\mathrm{GH}-15060$ & 2.04a-h & $4.02 \mathrm{f}-\mathrm{j}$ & $2.13 \mathrm{e}-\mathrm{k}$ \\
\hline $\mathrm{CP}-818$ & $2.40 \mathrm{a}-\mathrm{g}$ & $4.35 \mathrm{c}-\mathrm{g}$ & $2.58 b-f$ & $\mathrm{GH}-15688$ & $1.67 \mathrm{gh}$ & $3.03 n-p$ & $1.09 \mathrm{n}$ \\
\hline $\mathrm{P}-3550$ & $2.17 \mathrm{a}-\mathrm{h}$ & $4.27 \mathrm{~d}-\mathrm{i}$ & $2.53 \mathrm{~b}-\mathrm{g}$ & $\mathrm{GH}-15305$ & $2.19 \mathrm{a}-\mathrm{h}$ & $4.24 \mathrm{~d}-\mathrm{i}$ & $2.33 \mathrm{c}-\mathrm{i}$ \\
\hline $\mathrm{P}-3401$ & $2.42 \mathrm{a}-\mathrm{g}$ & $4.37 \mathrm{c}-\mathrm{g}$ & $2.60 b-f$ & BRMH - 1 & $1.85 \mathrm{~d}-\mathrm{h}$ & $3.341-0$ & $1.36 \mathrm{j}-\mathrm{n}$ \\
\hline$D-4685$ & $2.78 \mathrm{ab}$ & $4.96 \mathrm{ab}$ & $3.24 \mathrm{ab}$ & $\mathrm{H}-628$ & $1.71 \mathrm{f}-\mathrm{h}$ & $3.09 n-p$ & $1.13 n$ \\
\hline $\mathrm{D}-4114$ & 2.21a-h & $4.32 \mathrm{c}-\mathrm{h}$ & $2.55 \mathrm{~b}-\mathrm{g}$ & $\mathrm{DMH}-1$ & $1.85 \mathrm{~d}-\mathrm{h}$ & $3.301-0$ & $1.28 \mathrm{k}-\mathrm{n}$ \\
\hline DMH - 1107 & $2.53 \mathrm{a}-\mathrm{e}$ & $4.46 b-f$ & 2.88a-e & DMH - 3 & $2.13 a-h$ & $4.19 \mathrm{e}-\mathrm{i}$ & $2.21 \mathrm{~d}-\mathrm{j}$ \\
\hline GK - 3059 & $2.63 a-d$ & $4.81 \mathrm{a}-\mathrm{d}$ & $3.08 \mathrm{a}-\mathrm{d}$ & $\mathrm{DMH}-21$ & $1.82 \mathrm{~d}-\mathrm{h}$ & $3.68 \mathrm{i}-\mathrm{m}$ & $1.48 \mathrm{i}-\mathrm{n}$ \\
\hline GK -3150 & $2.68 \mathrm{a}-\mathrm{c}$ & $4.87 a-c$ & $3.19 a-c$ & Mean & 1.85 & 3.54 & 1.59 \\
\hline $740-$ deluxe & $1.92 \mathrm{c}-\mathrm{h}$ & $3.93 \mathrm{f}-\mathrm{k}$ & $2.03 \mathrm{e}-\mathrm{m}$ & Range & 1.51-2.19 & $2.64-4.24$ & $1.16-2.33$ \\
\hline BISCO PRINCE & 2.08a-h & $4.09 \mathrm{f}-\mathrm{j}$ & $2.28 \mathrm{~d}-\mathrm{i}$ & S.Em \pm & 0.11 & 0.06 & 0.13 \\
\hline NMH - 145 & $1.67 \mathrm{gh}$ & $3.42 \mathrm{k}-\mathrm{o}$ & $1.58 \mathrm{~h}-\mathrm{m}$ & C. D. at $5 \%$ & 0.32 & 0.17 & 0.38 \\
\hline CHAMUNDI & $2.56 a-e$ & $4.77 \mathrm{a}-\mathrm{e}$ & $3.02 \mathrm{a}-\mathrm{d}$ & & & & \\
\hline NANDINI & $2.13 a-h$ & $4.16 f-i$ & $2.37 \mathrm{c}-\mathrm{h}$ & & & & \\
\hline Mean & 2.26 & 4.27 & 2.51 & & & & \\
\hline Range & 1.67-2.83 & $3.42-5.03$ & $1.58-3.48$ & & & & \\
\hline
\end{tabular}


Table.2 Yield and yield traits of different maize hybrids

\begin{tabular}{|c|c|c|c|c|c|}
\hline Private hybrids & $\begin{array}{c}\text { Yield } \\
\left(\mathrm{kg} \mathrm{ha}^{-1}\right)\end{array}$ & $\begin{array}{c}\text { Cob length } \\
(\mathrm{cm})\end{array}$ & $\begin{array}{l}\text { Cob girth } \\
(\mathrm{cm})\end{array}$ & $\begin{array}{l}\text { No. of } \\
\text { rows }\end{array}$ & $\begin{array}{c}100 \text { seed } \\
\text { wt. (g) }\end{array}$ \\
\hline DKC - 9141 & $11492 \mathrm{a}$ & $16.9 \mathrm{a}-\mathrm{f}$ & $15.7 \mathrm{ab}$ & $14.8 \mathrm{ab}$ & $40.5 a$ \\
\hline DKC - 9133 & $9402 \mathrm{i}$ & $15.6 \mathrm{c}-\mathrm{j}$ & $14.4 a-f$ & $12.4 d$ & $37.1 \mathrm{a}-\mathrm{d}$ \\
\hline 900M - GOLD & $10170 \mathrm{~d}$ & $17.7 \mathrm{a}-\mathrm{c}$ & $15.6 a-c$ & $15.1 \mathrm{a}$ & 34.7d-h \\
\hline DKC - 9149 & $9479 \mathrm{~h}$ & 17.1a-e & $14.9 \mathrm{a}-\mathrm{e}$ & $12.8 \mathrm{~cd}$ & 34.7d-h \\
\hline DKC - 9126 & $9509 \mathrm{~h}$ & $16.6 \mathrm{a}-\mathrm{g}$ & $15.3 \mathrm{a}-\mathrm{e}$ & $13.1 b-d$ & $36.3 b-e$ \\
\hline DKC - 9144 & $9227 \mathrm{j}$ & $16.8 \mathrm{a}-\mathrm{g}$ & $14.6 a-f$ & $12.6 \mathrm{~d}$ & $32.4 \mathrm{f}-\mathrm{i}$ \\
\hline $\mathrm{NK}-6240$ & 88011 & $15.3 \mathrm{~d}-\mathrm{k}$ & 14.9a-e & $12.1 \mathrm{~d}$ & $39.0 \mathrm{a}-\mathrm{c}$ \\
\hline$S-6668$ & $10123 d$ & $16.6 \mathrm{a}-\mathrm{g}$ & $15.0 \mathrm{a}-\mathrm{e}$ & $13.3 \mathrm{a}-\mathrm{d}$ & $37.5 \mathrm{a}-\mathrm{d}$ \\
\hline $\mathrm{CP}-818$ & $10003 \mathrm{e}$ & $18.4 \mathrm{a}$ & $15.6 a-c$ & $13.1 \mathrm{~b}-\mathrm{d}$ & $36.0 \mathrm{c}-\mathrm{g}$ \\
\hline$P-3550$ & $9765 f$ & $16.0-\mathrm{i}$ & $14.9 \mathrm{a}-\mathrm{e}$ & $13.7 \mathrm{a}-\mathrm{d}$ & $38.0 \mathrm{a}-\mathrm{d}$ \\
\hline $\mathrm{P}-3401$ & $10037 \mathrm{e}$ & $17.2 \mathrm{a}-\mathrm{d}$ & $16.0 \mathrm{a}$ & $14.6 \mathrm{a}-\mathrm{c}$ & 37.0a-d \\
\hline $\mathrm{D}-4685$ & $11487 a$ & $18.0 \mathrm{ab}$ & $15.5 \mathrm{a}-\mathrm{d}$ & $13.9 a-d$ & $40.0 \mathrm{ab}$ \\
\hline $\mathrm{D}-4114$ & $9794 f$ & 17.0a-f & $14.8 \mathrm{a}-\mathrm{f}$ & $13.1 b-d$ & 37.0a-d \\
\hline DMH - 1107 & $10174 d$ & $16.5 \mathrm{a}-\mathrm{g}$ & $15.2 \mathrm{a}-\mathrm{e}$ & $13.1 \mathrm{~b}-\mathrm{d}$ & 37.6a-d \\
\hline GK -3059 & $10396 c$ & $15.7 \mathrm{c}-\mathrm{j}$ & $15.5 \mathrm{a}-\mathrm{d}$ & $13.9 a-d$ & 37.0a-d \\
\hline $\mathrm{GK}-3150$ & $11129 b$ & 16.9a-f & $16.0 \mathrm{a}$ & $14.9 \mathrm{ab}$ & 39.0a-c \\
\hline $740-$ deluxe & $9355 i$ & $16.0 \mathrm{~b}-\mathrm{i}$ & 15.1a-e & $13.0 \mathrm{~b}-\mathrm{d}$ & 35.0d-h \\
\hline BISCO PRINCE & $9522 \mathrm{~h}$ & $15.2 \mathrm{~d}-\mathrm{k}$ & $15.6 a-c$ & $13.5 \mathrm{a}-\mathrm{d}$ & 37.0a-d \\
\hline $\mathrm{NMH}-145$ & $8511 \mathrm{~m}$ & $14.8 f-k$ & 14.1b-f & $13.7 a-d$ & $36.0 \mathrm{c}-\mathrm{g}$ \\
\hline CHAMUNDI & $10383 c$ & 17.0a-f & $15.4 a-e$ & $14.8 \mathrm{ab}$ & 31.8hi \\
\hline NANDINI & $9577 \mathrm{~g}$ & $16.2 \mathrm{a}-\mathrm{h}$ & $15.3 \mathrm{a}-\mathrm{e}$ & $12.8 \mathrm{~cd}$ & $38.0 \mathrm{a}-\mathrm{d}$ \\
\hline Mean & 9921 & 16.5 & 15.2 & 13.5 & 36.7 \\
\hline Range & 8511-11492 & 14.8-18.4 & $14.1-16.0$ & $12.0-15.2$ & $32.4-40.5$ \\
\hline \multicolumn{6}{|l|}{ Public hybrids } \\
\hline $\mathrm{GH}-150241$ & $8221 n$ & $13.9 \mathrm{i}-1$ & $15.0-\mathrm{e}$ & $13.7 \mathrm{a}-\mathrm{d}$ & $37.0 \mathrm{a}-\mathrm{d}$ \\
\hline $\mathrm{GH}-0727$ & $6953 v$ & $13.2 \mathrm{kl}$ & $13.1 \mathrm{f}$ & $12.4 \mathrm{~d}$ & $33.0 \mathrm{e}-\mathrm{i}$ \\
\hline $\mathrm{GH}-1427$ & $7419 t$ & $14.6 \mathrm{~g}-\mathrm{k}$ & $13.8 \mathrm{c}-\mathrm{f}$ & $12.2 \mathrm{~d}$ & $35.2 \mathrm{~d}-\mathrm{h}$ \\
\hline $\mathrm{GH}-1436$ & $7867 q$ & $15.5 \mathrm{c}-\mathrm{j}$ & $14.0 \mathrm{~b}-\mathrm{f}$ & $13.1 \mathrm{~b}-\mathrm{d}$ & 35.0d-h \\
\hline $\mathrm{CAH}-1574$ & $8097 p$ & $15.7 \mathrm{c}-\mathrm{j}$ & $13.6 \mathrm{ef}$ & $12.6 \mathrm{~d}$ & 35.0d-h \\
\hline $\mathrm{GH}-1314$ & $6631 \mathrm{w}$ & $13.6 \mathrm{j}-1$ & $13.7 d-f$ & $12.1 \mathrm{~d}$ & $30.0 \mathrm{ij}$ \\
\hline $\mathrm{GH}-1316$ & $8170 \mathrm{o}$ & $15.8 \mathrm{~b}-\mathrm{j}$ & $14.1 \mathrm{~b}-\mathrm{f}$ & $12.8 \mathrm{~cd}$ & 35.0d-h \\
\hline $\mathrm{GH}-15060$ & $8861 \mathrm{k}$ & $16.4 \mathrm{a}-\mathrm{g}$ & $14.4 \mathrm{a}-\mathrm{f}$ & $13.0 \mathrm{~b}-\mathrm{d}$ & $36.0 \mathrm{c}-\mathrm{g}$ \\
\hline $\mathrm{GH}-15688$ & $6648 w$ & 12.51 & $13.8 \mathrm{c}-\mathrm{f}$ & $12.6 \mathrm{~d}$ & $28.0 \mathrm{j}$ \\
\hline $\mathrm{GH}-15305$ & $9227 j$ & $15.1 \mathrm{~d}-\mathrm{k}$ & $15.3 \mathrm{a}-\mathrm{e}$ & $14.0 a-d$ & $32.3 \mathrm{~g}-\mathrm{i}$ \\
\hline BRMH - 1 & $7598 \mathrm{r}$ & 14.1h-1 & $15.4 \mathrm{a}-\mathrm{e}$ & 13.9a-d & $36.1 \mathrm{c}-\mathrm{f}$ \\
\hline $\mathrm{H}-628$ & $7219 u$ & $15.4 \mathrm{~d}-\mathrm{j}$ & $13.9 \mathrm{~b}-\mathrm{f}$ & $12.8 \mathrm{~cd}$ & $30.0 \mathrm{ij}$ \\
\hline DMH - 1 & $7539 \mathrm{~s}$ & $15.0 \mathrm{~d}-\mathrm{k}$ & 15.0a-e & $12.1 \mathrm{~d}$ & $30.0 \mathrm{ij}$ \\
\hline DMH - 3 & $8873 \mathrm{k}$ & $15.4 d-j$ & $15.4 \mathrm{a}-\mathrm{e}$ & $13.5 \mathrm{a}-\mathrm{d}$ & $37.5 \mathrm{a}-\mathrm{d}$ \\
\hline DMH -21 & $7641 r$ & $14.9 \mathrm{e}-\mathrm{k}$ & 14. 7a-f & $12.6 \mathrm{~d}$ & $36.0 \mathrm{c}-\mathrm{g}$ \\
\hline Mean & 7798 & 15 & 14 & 13 & 33.7 \\
\hline Range & 6631-9227 & 12.5-16.4 & 13.1-15.4 & 12.1-14.0 & 28.0-37.5 \\
\hline S.Em \pm & 585.25 & 0.83 & 0.54 & 0.62 & 2.38 \\
\hline C. D. at $5 \%$ & 1680.25 & 2.39 & 1.56 & 1.78 & 6.83 \\
\hline
\end{tabular}


Table.3 Correlation table for the dependent and independent variables

\begin{tabular}{|l|l|l|l|l|l|l|l|l|}
\hline Correlation & $\begin{array}{l}\text { Yield } \\
\mathbf{k g ~ h a}^{-1} \mathbf{)}\end{array}$ & $\begin{array}{l}\text { Cob } \\
\text { length } \\
\text { (cm) }\end{array}$ & $\begin{array}{l}\text { Cob } \\
\text { girth } \\
\text { (cm) }\end{array}$ & $\begin{array}{l}\text { No. of } \\
\text { rows }\end{array}$ & $\begin{array}{l}\text { Test wt. } \\
\text { (g) }\end{array}$ & $\begin{array}{l}\text { LAI 30 } \\
\text { DAS }\end{array}$ & $\begin{array}{l}\text { LAI 70 } \\
\text { DAS }\end{array}$ & $\begin{array}{l}\text { LAI at } \\
\text { harvest }\end{array}$ \\
\hline Yield (kg/ha) & 1 & - & - & - & - & - & - & - \\
\hline Cob length $(\mathbf{c m})$ & $0.830^{* *}$ & 1 & - & - & - & - & - & - \\
\hline Cob girth (cm) & $0.796^{* *}$ & $0.600^{* *}$ & 1 & - & - & - & - & - \\
\hline No. of rows & $0.662^{* *}$ & $0.449^{* *}$ & $0.688^{* *}$ & 1 & - & - & - & - \\
\hline Test wt. (g) & $0.403^{*}$ & $0.360^{*}$ & $0.403^{*}$ & 0.189 & 1 & - & - & - \\
\hline LAI 30 DAS & $0.904^{* *}$ & $0.729^{* *}$ & $0.772^{* *}$ & $0.748^{* *}$ & $0.395^{*}$ & 1 & - & - \\
\hline LAI 70 DAS & $0.949^{* *}$ & $0.763^{* *}$ & $0.777^{* *}$ & $0.715^{* *}$ & $0.418^{*}$ & $0.946^{* *}$ & 1 & - \\
\hline LAI at harvest & $0.963^{* *}$ & $0.756^{* *}$ & $0.768^{* *}$ & $0.720^{* *}$ & $0.421^{*}$ & $0.958^{* *}$ & $0.978^{* *}$ & 1 \\
\hline
\end{tabular}

$*$ Correlation is significant at $5 \%$ C.D, and $* *$ Correlation is significant at $1 \%$ C.D

Whereas the lowest number of rows per cob was noticed in hybrid NK-6240 with 12.1 rows and was closely followed by DKC-9133 (12.6). Within the public hybrids the number of grain rows per cob varied from 12.1 to 14.0 , with the mean of 13.0 rows. The highest number of grain rows was recorded by hybrid GH-15305 (14.0) and was closely followed by BRMH-1 (13.9) and GH-150241 (13.7). Whereas the lowest number of grain rows per cob was noticed in hybrid GH-1314 (12.1) and was closely followed by DMH-1 (12.1) and GH-1427 (12.2) (Table 3).

The test weight of grains among the private hybrids varied from 32.4 to $40.5 \mathrm{~g}$, with the mean value of $36.7 \mathrm{~g}$. The highest test weight was recorded by the hybrid DKC-9141 (40.5 g) followed by D-4685 (40.0 g) and GK-3150 $(39.0 \mathrm{~g})$. The lowest test weight was recorded by the hybrid CHAMUNDI (31.8 g) and was closely followed by DKC-9144 (32.4 g). The test weight of grains among the public hybrids varied from 28.0 to $37.5 \mathrm{~g}$, with the mean value of $33.7 \mathrm{~g}$. The highest test weight was recorded by the hybrid DMH-3 (37.5 g) followed by GH15024 (37.0 g) and BRMH-1 (36.1 g). The lowest test weight was recorded by the hybrid GH-15688 (28.0 g), which was closely followed by H-628 (30.0 g) and DMH-1 (30.0 g). Younas et al., (2002) conducted an experiment on twelve hybrids to evaluate the yield and yield associated traits of maize hybrids. Results indicated that hybrids were significantly different from each other for all the characters such as the ear length which was found to be highest in hybrid $3130(20.46 \mathrm{~cm})$, while the minimum ear length was recorded by hybrid Super early $(16.75 \mathrm{~cm})$. maximum kernel rows per ear i.e. 15 rows was obtained for Pop-9815, 100 kernel weight of $39.5 \mathrm{~g}$ was observed in hybrid Ghauri, maximum grain yield $(9916 \mathrm{~kg}$ $\mathrm{ha}^{-1}$ ) was obtained from hybrid C-919, minimum grain yield (6846 $\left.\mathrm{kg} \mathrm{ha}^{-1}\right)$ and maximum days to $50 \%$ silking (63) was recorded by hybrid 3043 .

\section{Grain yield ( $\left.\mathrm{kg} \mathrm{ha}^{-1}\right)$}

The grain yield among private hybrids varied from 8511 to $11492 \mathrm{~kg} \mathrm{ha}^{-1}$ with the mean value of $9921 \mathrm{~kg} \mathrm{ha}^{-1}$ The study revealed that among the private maize hybrids tested, DKC-9141 gave the highest yield of $11492 \mathrm{~kg} \mathrm{ha}^{-1}$ and was closely followed by D-4685 (11487 kg ha-1), which was at par with former, and, the next best was GK-3150 (11129 $\mathrm{kg} \mathrm{ha}^{-1}$ ). The hybrid $\mathrm{NMH}-145$ with yield of $8511 \mathrm{~kg} \mathrm{ha}^{-1}$ recorded the lowest yield among the private hybrids followed by NK-6240 kg ha ${ }^{-1}$. Amongst the public hybrids, the grain yield ranged from 6631 to $9227 \mathrm{~kg} \mathrm{ha}^{-1}$ with the mean of $7798 \mathrm{~kg}$ ha $^{-1}$. Hybrid GH-15305 recorded the highest yield of $9227 \mathrm{~kg} \mathrm{ha}^{-1}$ closely followed by DMH3 (8873 $\left.\mathrm{kgha}^{-1}\right)$ and GH-15060 (8861 kg ha $\left.{ }^{-1}\right)$. Whereas the lowest yield of $6631 \mathrm{~kg} \mathrm{ha}^{-1}$ was 
recorded by hybrid GH-1314 which was on par with GH-15688 (6648 $\left.\mathrm{kg} \mathrm{ha}^{-1}\right)$.

Among all the hybrids the private hybrids outperformed the public hybrids in terms of yield. The highest yield in private hybrids was recorded by DKC-9141 with yield of $11492 \mathrm{~kg}$ $\mathrm{ha}^{-1}$. The mean yield of private hybrids was $9921 \mathrm{~kg} \mathrm{ha}^{-1}$. Whereas the highest yield in public hybrids was recorded by GH-15305 with yield of $9227 \mathrm{~kg} \mathrm{ha}^{-1}$ and the mean yield being $7798 \mathrm{~kg} \mathrm{ha}^{-1}$. While assessing the performances of three genotypes, it was observed that DMH-1 registered higher yield than Deccan-103 and Prabha composites. DMH-1 recorded higher yield of $\quad(8884 \quad \mathrm{~kg}$ $\left.\mathrm{ha}^{-1}\right)$ as compared to that of Deccan-103 (5050 $\mathrm{kg} \mathrm{ha}^{-1}$ ) and Prabha (4953 $\left.\mathrm{kg} \mathrm{ha}^{-1}\right)$ Singh et al., (1993).

The correlation analysis revealed that there was highly significant correlation between LAI, cob length, cob girth, number of rows and grain yield, whereas, test weight had significant correlation. The yield components such as cob length and cob girth showed to have stronger correlation with yield compared to number of rows and test weight. The LAI at all the three stages had highly significant correlation with yield.

The comparison of the yield levels of private and public maize hybrids showed that the private hybrids outperformed the public hybrids in terms of grain yield with the highest among private hybrid being DKC-9141 (11492 $\left.\mathrm{kg} \mathrm{ha}^{-1}\right)$ compared with the highest among public hybrid GH-15305 (9227 kg ha $\left.{ }^{-1}\right)$. The yield difference between the best private and best public hybrid was 19.8 per cent. The lowest yield was recorded by a private hybrid NMH-145 (8511 $\mathrm{kg} \mathrm{ha}^{-1}$ ) in comparison to the lowest yield of public hybrid GH-1314 (6631 $\left.\mathrm{kg} \mathrm{ha}^{-1}\right)$ with a yield difference of 22.1 per cent between these two hybrids. Ahmed et al., (2007) carried out a study in Faisalabad on maize with three maize hybrids i.e., DK-919, DK-5219 and Pioneer 30Y87. They observed that DK-919 produced 19.0 and 18.0 per cent more total dry matter over DK-5219 and Pioneer 30Y87, respectively, suggesting variation amongst different maize hybrids with regard to potential yield.

\section{References}

Ahmed, M., Bukshs, H. A., Ahmed, R., Malik, A. U. Hussain, S. and Ishaque, M., 2007, Agro physiological traits of three maize hybrids as influenced by varying plant density. The Journal of Animal \& Plant Sciences, 20: A-35.

Dahmardeh and Dahmardeh (2010) the effect of sowing dates on some growth physiological index on grain yield in three maize hybrids in Southeastern Iran. Asian Journal of Plant Sciences, 9 (7): 432-436.

Hara, A., 2003, Performance of maize hybrids in relation to planting dates and nitrogen level. M. Sc Thesis, Punjab Agricultural University, Ludhiana.

Haroon, Z. M., Shahid Iqbal, Asif Iqbal, Nadeem Akabar, and Davey, L. J., 2011, Response of maize varieties to different levels of nitrogen. Crop and Environment, 2(2): 15-19.

Singh, S. P., Gour, B. L., Shet and Hawal, 1993, Effect of cultivar spacing and nitrogen fertilization on yield and nutrient uptake by maize Annals of Agricultural Research, 13, pp. 277-279.

Younas, M., Hayder, G. and Ahmed, H., 2002, Magnitude of variability for yield and yield associated traits in maize hybrids. Asian Journal of Plant Science, 387-392.

\section{How to cite this article:}

Pradeep, M.G. and Patil, R.H. 2018. Evaluation of Private and Public Maize Hybrids for their Potential Yield Under Northern Transition Zone of Karnataka, India. Int.J.Curr.Microbiol.App.Sci. 7(1): 3565-3571. doi: https://doi.org/10.20546/ijcmas.2018.701.418 